Innlegg på inntil $\mathbf{4 0 0}$ ord lastes opp i http://mc.manuscriptcentral.com/tidsskriftet.

Redaksjonen forbeholder seg retten til å foreta redaksjonelle endringer.

Forfattere av vitenskapelige artikler har tilsvarsrett (jf. Vancouver-gruppens regler).

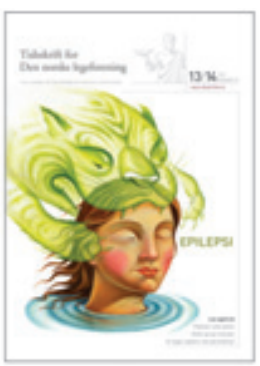

\section{Vaginalblødning også faresignal}

Jeg vil få kommentere «Utredning ved sterk mistanke om kreft» av Sølve Hodnestad i Tidsskriftet nr. 13-14/ 2011(1). Jeg har ingen problemer med å støtte forfatteren i hans syn på at utredning skal igangsettes snarlig ved symptomer som umiddelbart leder vår oppmerksomhet mot å bekrefte eller avkrefte diagnosen kreft så snart som mulig. Men når forfatteren lister opp symptomene «blødning» og «svulster/knuter» savner jeg symptomer som bare kvinner opplever. Når hematuri og vedvarende blødning i avføringen nevnes, burde det være en selvfølge å nevne vaginalblødning hos postmenopausale som et like alvorlig faresignal. Med hensyn til svulster så kunne jo også gynekologiske tumorer nevnes, men jeg er enig $i$ at listen bør være kort og konsis.

Etter over 25 år som lege i gynekologi og obstetrikk var denne utelatelsen (forglemmelsen?) noe som gjorde meg noe trist. Selv om forfatteren tilhører en annen spesialitet, så gjelder innlegget forhåpentligvis begge kjønn? Vaginalblødning uten «grunn» har jo i alle år vært et av de ti faresignalene til Kreftforeningen. Ansvarlig redaktør for spalten Anne Kveim Lie burde ha «fanget opp» dette - etterdet jeg forstår, så har hennes interessefelt gått delvis i retning av gynekologiske problemstillinger/ medisinsk historie (det siste er jo i denne sammenhengen også interessant).

\section{Anne Tollan}

Hoddles Creek, Victoria

Australia

Anne Tollan (f. 1954) er spesialist i fødselshjelp og kvinnesykdommer.

Ingen oppgitte interessekonflikter.

\footnotetext{
Litteratur

1. Hodnestad S. Utredning ved sterk mistanke om kreft. Tidsskr Nor Legeforen 2011; 131: 1282.
}

\section{Hjerneslag - nevrologi og tverrfaglighet}

Antje Reichenbach og medarbeidere presenterer i Tidsskriftet nr. 9-10/2011 det lokale opplegget for hjerneslagbehandling ved Oslo universitetssykehus, Ullevål (1).

Etter vårt skjønn representerer organiseringen i Oslo en uheldig medisinsk logistikk. Oslos befolkning har per i dag ikke tilbud om slagbehandling med samlet nevrologisk, nevrokirurgisk og nevroradiologisk spisskompetanse på ett sted. Det øker risikoen for tidstap når det gjelder å oppnå rask rekanalisering av arteriene. Artikkelen redegjør godt for reparativ rehabilitering, men den underestimerer viktigheten av preventiv akuttmedisin og behovene for barn, ungdom og unge voksne med hjerneslag.

Forfatterne skriver: «Det nevrologiske vaktteamet beholder det medisinske ansvaret for pasientene frem til morgenen etter innleggelsen [...] Dette er hensiktsmessig, siden akutt forverring i den subakutte fasen som regel skyldes indremedisinske / geriatriske komplikasjoner som infeksjoner, hjerte- og karhendelser, delirium og tromboemboliske tilstander.» $\mathrm{Vi}$ vurderer denne praktiseringen av standardmessig ansvarsoverføring etter ett døgn til annet personale som lite hensiktsmessig. Akutt sykdom i hjernens arterier har elementer av dynamiske prosesser med bedrings- og forverringsmuligheter utover ett døgn. Nevrologisk ekstra- og transkranial ultralyd er et nyttig verktøy for overvåking, og ultralyd vil også kunne utnyttes til akutte terapeutiske formål. Til dels er det nødvendig med gjentatte undersøkelser påfølgende dager for å få innblikk i forandring av hemodynamiske prosesser, som for eksempel arteriedisseksjoner hos yngre pasienter. Yngre pasienter er også mer sårbare for malignt ødem og bør ha samme behandlerteam rundt seg inntil tilstanden er stabil. God kontinuitet gir større trygghet for et godt behandlingsresultat. Det er også viktig å være oppmerksom på at akutte nevrologiske utfall ikke alltid skyldes hjerneslag. Differensialdiagnoser som sinusvenetrombose, hjernetumor, encefalitt, migrene, epilepsi m.m. tilsier at nevrologisk og nevroradiologisk kompetanse er nødvendig for en korrekt diagnose, også utover de første timene.

Dersom pasienten har en ikke-vaskulær, men intrakranial, sykdom, bør pasienten følges ved en nevrologisk enhet med spisskompetanse på feltet. Dersom pasienten har en infeksjon eller annen indremedisinsk sykdom, og mistanken om hjerneslag blir avkreftet, bør pasienten følges ved en medisinsk avdeling. Pasienter med hjerneslag krever tett og kontinuerlig hjerneovervåking og personalet på slagenheter må kunne fokusere på de rette pasienter. Godt samarbeid med kolleger innen kardiologi, indremedisin og geriatri er avgjørende for korrekt plassering og best mulig behandling av pasienter med slagliknende symptomer uten hjerneslag. Oslo har alle ressurser med nevrologisk, nevrokirurgisk og nevroradiologisk spisskompetanse tilgjengelig per i dag, men det er uforståelig for oss at denne ikke er samlet effektivt på ett sted. Uten tvil er slagbehandling en stor og kompleks utfordring med behov for godt og tett tverrfaglig samarbeid med kolleger som har spisskompetanse i nevrologi, kardiologi, indremedisin, geriatri og rehabilitering.

\section{Ulrike Waje-Andreassen}

Halvor Næss

Nevrologisk avdeling

Haukeland universitetssykehus

\section{Martin W. Kurz}

Nevrologisk avdeling

Stavanger universitetssjukehus

\section{Rolf Salvesen}

Nevrologisk avdeling

Nordlandssykehuset, Bodø

Ulrike Waje-Andreassen (f. 1962) er ph.d. og overlege ved slagpost, Nevrologisk avdeling, Haukeland universitetssykehus.

Halvor Næss (f. 1957) er dr.med. og overlege ved slagpost, Nevrologisk avdeling. Haukeland universitetssykehus.

Martin W. Kurz (f. 1975) er ph.d. og seksjonsoverlege ved slagpost, Nevrologisk avdeling, Stavanger universitetssjukehus.

Rolf Salvesen (f. 1952) er professor dr.med. og avdelingsoverlege ved Nevrologisk avdeling. Nordlandssykehuset, Bodø.

Litteratur

1. Reichenbach A, Celius EG, Fure B et al. Hjerneslagbehandling - en tverrspesialisert utfordring. Tidsskr Nor Legeforen 2011; 131: 934-6. 